\title{
[An Epistemological Analysis of] Predestination and Free-Will in John Milton's Paradise Lost
}

\author{
Sayyed Vahid Abtahi \\ Islamic Azad University, Karaj Branch, Iran \\ E-mail: fellowayfarer@gmail.com
}

Received: 22-12-2013

doi:10.7575/aiac.ijalel.v.3n.3p.83
Accepted: 29-01-2014

Published: 01-05-2014

URL: http://dx.doi.org/10.7575/aiac.ijalel.v.3n.3p.83

\begin{abstract}
Paradise Lost by John Milton is one of the most important literary works of the seventeenth century. In this epic in verse Milton, by displaying a portrait that combines Greek Mythology and Christian teachings, seeks to elucidate Divine Providence and man's relation with God's decree. He puts together Divine will-power and human determination to make the meaning understood of the Man's Fall. Milton first adhered to Calvin's school with regard to determinism and free will but afterward he turned to Arminianism. In Calvinism, it is believed that man's fall has been registered in God's eternal knowledge, that is, the Fall was to happen according to the will of God from the beginning. Therefore, both the prosperity and salvation of humankind are dependent upon God's decision. However, in the Arminius' school, it is believed that man is free and has authority to either accept or reject the Divine favor. From Milton's viewpoint, predestination is God's foreknowledge about the occurrence of events not about the creation of events. Consequently, if we consider man's will-power on the basis of this belief of Milton, man may also become possessed of Divine decision (Divine will-power).
\end{abstract}

Keywords: Arminius, Freedom of will, predestination, determinism, salvation, Calvin, prosperity

\section{Introduction}

The seventeenth and eighteenth centuries are thought to be the age of enlightenment and Man's self-actualization in contrast with God's authenticity in the Middle Ages. With regard to this, elucidating the affairs on the basis of Divine Providence and Will-power in the Middle Ages was replaced by explaining events according to the centrality of man's qualities such as free-will and determination. Milton's strong belief in and intense tendency toward Man caused him to compile Paradise Lost. As a Christian, he both attended to reading the New Testament and had a liking for the Old Testament texts written in Hebrew. Nevertheless, he extolled Protestantism believing that Christianity needed reformation and re-interpretation. He refrained from dogmatism in Christianity but had his own creed concerning man's prosperity and human end of life.

The question of free-will and predestination has motivated lots of challenges in the intellectual circles of the West since the time of Plato and Aristotle, the main factor of which seems to be the exceptional attention of Christianity paid to ethic. Men's feeling of playing an active part together with their ethical responsibility necessitates their doing a good deed or avoiding doing an evil. Christian sages have accepted that no major force may affect our volition. They may compel us to perform a job but cannot coerce us into deciding to do some job. The moral principles of Aristotle too, are expressive of this philosopher's special attitude toward human free-will. In his opinion, the man's option is a voluntary decision made by their rational deliberation. Afterward, Christian thinkers emphasized this rationality so much that it caused St. Anselm to make a distinction between "option" and free-will. He believed that option or choice was a natural action arisen from enthusiasm and excitement, but free-will was a decision based on reason, which was subject to the light of knowledge. Duns Scotus, who was against such a distinction, believed that "intellect" was in human nature; therefore we might not differentiate between passionate, enthusiastic determinations and rational, intellectual decisions. Whatever is issued from humans is the result of their rational demands. Also, Aristotle reasoned: If a decision has not originated from man's intellect, it is not based upon will-power; so, the application of the terms "option" or "willpower" should not be used for it, because a decision made out of sensuality with the action resulted from it means falling into the abyss of animality, which is far from humanity. However, Boethius believed that there is a difference between our will-power and our actions. In this regard, you should not say that putting everything into practice emanates from the will-power, because the animals could also be involved in the same judgment. So, will-power must only be attributed to humankind, because it emanates from their rational knowledge. Then, free-will must be the consequence of "reason" only.

Since the Christian sages considered voluntary actions arising from man's rationality, this caused the will-power to be regarded as innate in human beings. Thus, all thinkers from Augustine to Aquinas decided that Man's Fall should be taken as their free-will because this descension could not be in conflict with man's nature. Therefore, the commission of the first sin must have been through Man's choice, as the other sins after that were committed voluntarily out of his will- 
power. Then, those Christian sages were impressed by a logical definition of the word will-power from one side and affected by religious, valued explanations from the other. Therefore, when Augustine wanted to define the word "willpower", he made a distinction between ability and intention. In his view, if a person does something, this is the result of their intention not of their ability. Then, this reasoning brought about a question: The intention or desire for which there is no ability nor strength, cannot be called will-power! However, Augustine answered: The blessing and affection of God is involved in this matter as a support to it. Again, in the confirmation of that reason, Anselm said: This statement does not mean that God is the cause of all our actions, but you had better say that "ability is equal to intention or desire", otherwise; you should regard man to be without any effect. As for a person who decides to do something but they can't do it, we are not to say: They lack will-power because power and knowledge are the same thing. Besides, this means that the powerless person has not intended nor wanted anything as they must have. In other words, they don't have the power to decide, not that their decision is powerless. Augustine and Anselm believe that there is a distinction between free-will and bad option: Good deed is related to your free-will but bad deed is related to the way of your choosing. Free-will by nature provides us with the ability not to commit sins, but committing sins is not men's free-will; it is their choice. If choosing and free-will become linked together, prosperity will be attained. If the human dimension of the free-will, which is making a choice, is taken away from it, then the Divine choice will take its place and the real deliverance will be obtained. Afterward, this very judgment impressed Luther and Calvin so much that it caused them to a deal with the negation of human will-power (Gilson, 1936, p. 375). Anyhow, the discourse on these issues led to a significant schism in Christianity with regard to predestination and free-will, which influenced the shaped Milton's outlook on his creed very much.

\section{Calvinism-Arminianism}

Discussing the meaning of Divine eternal knowledge has its deep root in controversies between the two schools of Calvin and Arminius about the question of destiny or predestination. Here, we will have a brief look at the history of development of the thought in the Christian theology:

John Calvin (called Jean Calvin in French) was one of the important scholars and a great theologian, well-known in Christianity. His school of thought called Calvinism was the result of the movement "Protestantism". John Calvin like Martin Luther emphasized the necessity for a review and a reformation in the concepts of Bible. In the same way that Luther in Germany freed Christianity from the dominance of the Catholic Church, Calvin in France managed to change and give Christianity a new style by writing a book under the title Institutes of the Christian Religion in Geneva, which influenced Christianity very much in both France and Switzerland. Elucidating and explaining the principles of Protestantism in his book, Calvin founded a new educational method of religious teaching which was unlike that of Martin Luther, who thought it was easy and permissible for every Christian to be freed from God's anger. However, Calvin believed that deliverance from God's punishment was not feasible if Divine Providence had not been applied to it.

Calvin negated the Lutheran unconditional remission of sins in order to propound the absolute power of God. (Note) He believed that it was not permissible to question on God's actions since human rationalism or contemplation cannot perceive anything of God, the Great (Foster \& Rice, 1849, p. 21).

The eternal predestination and the absolute will of God is found at the core of theological system of Calvin (Foster \& Rice, 1849, p. 21). From his viewpoint, God has destined everybody for their fates - for some people prosperity and for some others adversity from the beginning (Calvin, 2007, p. 114; also see Hirsch, Kett \& Trefil). Calvin's fear in his theology for descension and for the sight of man's fall caused him to consider human power as base, ineffective and deviating. In his perspective, humanity is irreconcilable with divinity and sanctity; in his opinion, humanity has been an unblessed destiny with which God has affected humankind even before the man's Fall so that He might exert His chastisement on them (Calvin, p. 175).

The most important criticism that could be made for Calvin's teachings is that they are incompatible with rational and logical principles. Fatality renders many intellectual rules ineffective. This means, for the Christian believers, that the teachings of the Holy Book are irrational. That was the reason why Calvin's theology faced with great difficulties by drawing the attention of Christian thinkers (Foster \& Rice, 1849, p. 17).

\section{1 "Predestination" in Calvin's View}

Predestination or "destiny" has two meanings: general and particular. In its general sense, it pertains to the ontological dimension of life and in its particular sense, it deals with a cosmopolitan dimension. From an ontological perspective, Predestination is the dominance and governance of the Divine precepts over all the particles in existence. In this definition, God's will encompasses all the elements of entity whether concrete or abstract. In Calvin's view, God's commands are media of causing the Kingdom of God to act over the constituents of existence.

In its particular sense and as a concise definition, Predestination pertains to the fates of human beings in a specific way. According to John Calvin's definition in his theological system, predestination is a general, public decree which involves both "selection" and "rejection". The selecting precept will be exercised merely on the basis of the Divine order to His servants without the consideration of their merits and virtues. Here, Calvin does not mention any requisites for God's selection of people but makes the rejection conditioned to having committed some sins. To Calvin, just as the Divine grace causes prosperity, God's justice for punishment will be the medium of adversity, which leads to someone's rejection and deprivation (Girardeau, 1890, p. 10). 


\subsection{Arminianism}

Jacobus Arminius was a Dutch Theologian, who used to teach Christian theology in the University of Leiden. As John Calvin was committed to observe the principles of Reformation in the Protestant movement, Arminius learned theology from Theodore Beza, the successor of Calvin though he was familiar with Calvin's school very well. He followed that school of thought to the extent that the university asked him to defend John Calvin's pre-arranged doctrine against Coornhert's criticisms. But while reasoning in debate, he submitted to Coornhert's ideas and the rejected Calvin's teachings. Later, he was frequently assailed by Calvin's proponents on that regard.

Arminius' school of thought was established after his death and the movement called "Remonstrant Movement" is ascribed to him. Finally, after his viewpoints were set forth to the Council Synod of Dort, the members refused to accept them; instead, they approved Calvin's principles and ratified them.

Arminius' first treatise written against Calvinism includes 5 general bases (Remonstrances) with the core of his beliefs being laid upon "Irresistible or Prevenient Grace", which is something like God's bountiful grace. It is a blessing for which there are no conditions to be granted. He believes that God's grace and blessings suffice us to achieve Faith and salvation in spite of our involvement in sins: Being chosen as an authority is not necessary to realize and verify prosperity although the prosperous persons may have been the chosen too. The Divine grace is absolute and unconditional; it is not specific to a particular group or social class.

Arminius believed that confidence and Salvation do not belong to only the Chosen because the believers may also become subject to corruption and decline, and because the Divine antecedent knowledge does not warrant the decree of confidence. In his view, the eternal knowledge of God is merely an antecedent awareness that does not have any causal relation to Man's deeds. Faith is a blessing but it is not the requisite for superiority. The predestined superiority (supposedly) requires that you accept the trick and deceit of God, whereas people themselves determine their own ends (Arminius \& Nichols, 1853, pp. 278-99); they choose generosities according to their own free-will.

In the opinion of Arminius, however, the radiation of the Holy Spirit's blessing is predestined; it is like the shining of the sun which is the same over both the guilty and the innocent (Gonzalez, 1983, p. 257). Jack Cottrell (1984), a defender of Arminianism explains: God only chooses those who benefit from His bounteous grace. But even if somebody draws such blessings toward themselves and asks God earnestly with penitence, we may not say that they are honest persons because those blessings are only left at their disposal. In other words, since men are not by nature worthy of such blessings, we should say the blessings have been bestowed upon them by God. Cottrell believes that God had the foreknowledge about the worthiness of Jesus for the blessings; God knows from the beginning who deserves the favors and who does not, but God has not destined prosperity for anyone in their fates (pp. 57-61).

Now, the key point in these words is this: Anyone who agrees to God's favors such as Grace, Blessings, Faith, or Penitence and can verify them, they are said to be the doers or the actors not God; because it is Man who ultimately decides to do something. Issues such as Faith and Penitence have been naturally sent down to Men and been put at their disposal; Men are free to accept them or not. Therefore, on the basis of Arminius' school, eternal knowledge is that God knows about future events irrespective of His being the cause of them.

This means that Divine knowledge is a topic different from Divine destiny. According to His pervasive knowledge, God is aware of every event in the universe. He knows about the beginning, the end and the fate of everything; but He has not predestined their extremity and association; rather His knowledge gives Him evidence what destiny and end every being, with regard to their structure and shape, may produce for themselves (Robert Cook, 1990, p. 164). Which destiny God determines for men only pertains to Divine dignity. He pre-arranges the possibilities of the growth for all beings, but the acceptance of those responsibilities is left to the people. Sometimes man's destiny coincides with God's arrangement and sometimes they are against each other.

Arminius believes that men are responsible for their own deeds. The first Sin of Man (Man's Fall) does not involve anyone else's conviction (Arminius \& Nichols, 1853, p. 817). Faith is not the criterion for justice (Arminius \& Nichols, p. 363). To some extent Faith is emanated from blessing, not wholly. Rather, a part of it concerns man's free will and power (Arminius \& Nichols, p. 373). So, with regard to what was mentioned, we can conclude that Calvinistic predestination exactly stands against man's will-power to undermine the life value and Divine Justice. To Milton, the concept of Divine knowledge and justice and finally human fate from Calvin's viewpoint reaches a deadlock. In the same way, unconditional freedom of will-power does not convince Milton, who while narrating the story of Creation, concludes: Predestination and free-will are not contradictory or conflicting. Rather, they are complementary and supplemental. Therefore, this doctrine is called "Compatibilism".

\section{Predestination and Free Will in Milton's Perspective}

Having arranged, discussed and indicated the position of free-will, predestination and Christian theology, we will now proceed to elaborate on the topic in Milton's Paradise Lost. As we see, the poet tries to substantiate the Divine Blessing by elaborating on God's Providence (Paradise Lost I. 24-6). Nevertheless Milton says he wants to become informed of God's knowledge and defend His justice.

"The Defending of Free Will" in Milton's knowledge is one of the most essential topics in Paradise Lost. In this epic, the main challenge of the poet is that God has created both the angels and humans out of His expediency so as to see whether they obey or disobey His commands on the basis of their will-power. Such an attitude brings to our mind a sort of limitation in the absoluteness of God's knowledge, power or determination, because He cannot thoroughly dominate 
the willpower of men and angels anymore. But from Milton's standpoint, this does never impose any taint on the power of God because man's will-power is a kind of God's authority; it is the influence of His sovereignty over the world of beings. Milton quotes from God as follows:

I made [human beings] just and right,

Sufficient to have stood, though free to fall,

Such I created all the ethereal powers

And spirits, both them who stood and them who failed;

Freely they stood who stood, and fell who fell. (PL III. 89-93)

Milton believes that the value of virtues and good qualities such as honesty, faithfulness, truthfulness and love would be brought into question if without Free-will. If people did not enjoy will-power, how could they present their obedience to God?

Again Milton cites some of the arguments of Areopagitica:

And what is faith, love, virtue, unassayed

Alone, without exterior help sustained?

Let us not then suspect our happy state

Left so imperfect by the maker wise,

As not secure to single or combined.

Frail is our happiness, if this be so,

And Edenwere no Eden thus exposed. (PL IX. 335-41)

Milton (1953, p. 28), in Areopagitica, persists in the importance and the value of freedom. He considers it as the main attribute and the principal trait of beings with Faculty of Speech. Therefore, we should say: Benefiting from the freedom of determination - despite its wicked consequences - is the requisite for human perfection. God's granting power and freedom of choice, though it has caused deviation for some people, has not changed His ultimate wisdom and expedient anyhow.

From the arguments of Paradise Lost, it is understood that Milton draws a distinction between God's knowledge about the matters of the world and the Divine commands. From one side he considers God to be omnipotent, dominant over everything, and from the other side, he recognizes man to be able to control the affairs of life. With regard to human rationality and will-power, Milton shares the same ideas with Aristotle. Milton maintains that rationality is not the requisite for free-will, they are the same thing because the source and the end of them are the same (Milton, 1953, p. 28).

Milton believes that God's eternal knowledge about objects and events does not necessitate the use of force. He is of the same opinion as Augustine in this belief. In his well-known book on Free Power, Augustine (2010, p. 80) says: “The holy knowledge of God about what we will do in the future does never negate our free-will". So, "We will ascertain our will-power in the future because God has predestined our volition for the future" (Hyman \& Walsh, 1973, p. 60).

With regard to this, God says although He is omniscient and aware of everything beforehand, His prediction of prospective events will not affect their sins though their sins, which have not been committed yet, will surely occur (Paradise Lost III. 119).

This statement of Milton is expressive of the distinction there is between "certainty" and "necessity" in theology. Necessity pertains to the events themselves, while certainty concerns the knowledge about the events.

Thomas Pierce (1658, p. 128), one of the English churchmen and a famous preacher says in confirming the above statement: The Issuance of God's precepts and commands is inevitable. Then their occurrence is a necessity... But, what God initiates the capacity of is likely to happen. In this case, there is a certainty because His eternal knowledge is pure and devoid of errors. Thus the concept of certainty and possibility becomes interrelated.

Whatever is possible to occur is certain because it will certainly be performed, and God sees it in the same way it occurs. He sees it as an action which is done for certain; although its occurrence in this world is possible (Hammond, 1674, p. 586), therefore, the expression 119 from Paradise Lost can be interpreted like this:

The Man's Fall has "certainty", not "necessity", with this regard, and the Divine knowledge about the Fall is not followed by any predestination. Anicius Boethius has written in his book The Consolation of Philosophy, which is published on the Eternal Knowledge of God: "God has been present since eternity. He is the exalted of our time" (Danielson, 1999, p. 151). Whatever is present in our knowledge is present at the highest degree in God's knowledge. Boethius (1962, p. 116) also says: "The Divine knowledge is higher than and superior to that of all the creatures. Being 
possessed of such knowledge, God witnesses everything from His highest position". For this reason, Milton says in Paradise Lost: "from his prospect high, Wherein past, present, future he beholds" (Paradise Lost III. 77-8).

In order to consolidate his story, Milton tried to prepare and describe the required backgrounds both for the descension of Adam and Eve and for the prevention of their Fall. With regard to this, he points out that Adam and Eve have tackled their carnal desires and temptations in the pre-lapsarian life before their Fall. The observation of the scenes in which Adam and Eve get involved with temptations - Eve's sleep and Adam's being enamored - creates the mentality that they "had really fallen before their actual Fall". Here, demonstrating man's fallibility adds to the value of the narrative to make it more credible to the readers; but we should take it into our consideration that fallibility is not essentially the causal necessity for the Fall to happen.

Milton makes use of such a plot to pave the way for the substantiation of God's justice. For Milton, granting free-will to man, the occurrence of Man's Fall, and being contaminated with post-lapsarian sins do not ever reduce Divine justice (Hick, 1967, p. 139). But the occurrence of the fall despite the warning given in advance to Adam and Eve about the consequence of eating the forbidden fruit may bring this belief to the mind of some people that God granted man freewill and power in order to influence them, rule them and display His authority on them by keeping them in confinement. So, Milton warns the readers against such an imagination because, in his opinion and as Lovejoy justifies it, man's descension has been very auspicious and blessed. The paradox "Fortunate Fall" shows that Adam and Eve's sin must be taken as a "Desirable Guilt", and as Lovejoy (1969, p. 164) says "If it had not happened, Virgin Mary wouldn't have become pregnant to give birth to Jesus and the Salvation wouldn't have been realized".

In order to portray God's justice, Milton describes the event as follows:

Full of doubt I stand,

Whether I should repent me now of sin

By me done and occasioned, or rejoice

Much more, that much more good thereof shall spring,

To God more glory, more good will to men

From God... (PL XII. 473-8)

The point that should be remembered is this: If Adam and Eve had lived in world without sins, many a time their progeny in the future would have lived by far better than now, and God would have brought out more blessing than from within the evils. As Virginia Mollenkott $(1972$, p. 3) said "If no sin had occurred, how often, there would have been a more glorious and excellent future in prospect." God Himself says in Paradise Lost: "things would have been still "Happier, had it sufficed [man] to have known / Good by itself, and evil not at all" (II. 145-53).

In Milton's idea and from the viewpoint of many of his contemporaries accepting any form of fatality means rejecting free-will and negating free-will means rejecting Divine justice. Milton says in the Christian Doctrine: "Neither the commands of God nor His eternal justice would confine and restrain man's freedom." Otherwise, we should say: "God Himself would cause sins for the people" (Wolfe, 1953, p. 166).

In order to prove God's justice and fully emphasize it, Milton doesn't consider Man's Fall to be a will of God to give a privilege to man; rather, he believes that man, by the fall they have caused for themselves on their own, have made God's granting grace and blessings to them twice as much. In Paradise Lost, God says about this: "Man shall not be lost! ...Upheld by me, he shall stand once more; and to me alone he shall owe all his deliverance and to none but me ..." (III. 174-82).

John Goodwin (1651), an English preacher and theologian says:

God is not so poorly or meanly provided, in, and of himself, for the exaltation of his Name and Glory, as to stand in need of the dunghill of sin to make a foot-stool for him whereby to ascend into his Throne. If the goodness and righteousness of man be nothing unto God, profit not him, much less can the sins of men claim part and fellowship in such a business. So then the sins of men [are]...contrivable to his glory, but no ways requisite or necessary hereunto. (p. 40)

Milton first supported Calvin's school or Calvinism, but afterward, he was converted to Arminianism and followed his belief for God's absolute grace and blessings. Milton, who firmly believes in Divine justice states: The eternal favor of God "comes unprevented, unimplored, and unsought" to everybody (Paradise Lost III. 230-1). The favor of God causes those fallen to return to Him, but there are some men who deny that favor. They are those who will not benefit from His favor.

Then Milton says: "God does everything necessary for the happiness of man before and after Man's Fall, but the disbelievers deny God's unconditional favors, and they are in doubt about them" (Paradise Lost III. 231). Richard Baxter (1671, p. 923), the famous English theologian, who lived in the $17^{\text {th }}$ century, says in this regard: God's goodness 
is His very Name and His endless glory or splendor. It is the same goodness that leads the sinners toward penitence and renders their hearts afraid of His Name. It is His Name that renders Love aflame in our hearts, the love which is the cause of our sanctification and happiness. All of us know how much Divine blessing has been denied and rejected! (Also see Paradise Lost III. 144-173).

Milton's defending man's will-power does not mean that God's power cannot dominate human will-power. Milton depicts and elucidates free-will in the area of worshiping. He highlights worshiping with servitude and emphasizes its importance and superiority to start a new topic in the domain of ethic. So, we should say: The Fall entails "a move from pre-lapsarian autonomy achieved by obedience to a single command to post-lapsarian autonomy attained through obedience to the inner prompting of rigorous reason" (Schoenfeldt, 2003, p. 364).

In another statement you could say: During the days before the Fall, man benefited from the direct encounter with God, which enabled them to be informed of Divine commands and prohibitions. However, man's error caused them to descend, go away and then be deprived of that immediate contact. In the period after the Fall, man has been ordered to listen to their inner calls. They are led toward an intrinsic manner of living. With their descension, men are charged to seek help from their conscience call which is construed as waves linked to Divine voices. Such a connection being instituted and man's endeavor to keep it is of the important achievements after the Fall. God says in Paradise Lost:

And I will place within them as a guide

My umpire conscience, whom if they will hear,

Light after light well used they shall attain,

And to the end persisting, safe arrive. (PL III. 194-7)

Therefore in John Milton's theology, predestination is a subject the definition and realization of which is man's responsibility. Milton tries to show us that God has determined nothing but freedom and will-power for man. However, submission, imposition and coercion are on men's part. God says in this regard:

I formed them free, and free they must remain,

Till they enthrall themselves: I else must change

Their nature, and revoke the high Decree... (ㄴ III. 124-6)

Unlike the prevalent view which recognizes destination to be on God's part, in other words, unlike the common idea that man is destined on God's part to perform something; or "fate" is an imposition issued by God, Milton believes that predestination is some proportion detached from men's desires indicated for themselves.

In Paradise Lost, Milton tries hard to lead man's will-power toward morality by exaltation and refinement of men. His perspective in this regard, approaches that of Polus- Greek philosopher of fifth Century BC - to a large extent. In his opinion, free-will and the real rule of power become significant only when individuals can use their own insight and attitude apart from sensual and carnal demands. From this viewpoint, free-will is specific of those who prefer their freedom to the force and coercion of their selves; and it is in this case that we may call such persons "having freepower."

For Milton, the reason of God's granting free-will to man is that man may perceive their sinful condition so that they can commit themselves to God, by whom they ascertain their salvation. The fall of men is the result of their own option and the Ascension is the result of Divine choice.

\section{Conclusion}

Milton's theology consisting of concepts taken from ancient Greek mythology, Protestant Christianity, and ideations of Age of Enlightenment, considers man to be free and empowered. Milton does not approve of the man nourished in Calvinistic school of thought, who lacks authority and power, being an actor merely playing a pre-arranged role. Paradise Lost portrays a man whose thought is the reflection of God's decisions. Such a person will foresee occurrences before they are actualized and deliberate on them according to their own insight; and this is the same ideal point that God has determined for mankind and it is the antecedent knowledge about the events free from the confinement of time and place.

From the viewpoint of Milton, the coercive, fatalistic worship is not favorable to God; also, devotion to "self" is a kind of servility to it because Deliverance and Salvation mean that man should abandon carnal desires and prefer God's power to their own determination. From his perspective, virtues are valued when they are performed out of decision and volition; it is in this way that God pays Man's Fall because of voluntary efforts that are enthusiastically aimed for Him.

Finally, we ought to mention here that Milton juxtaposes Calvinistic predestination with Arminian free-will to make the relation between Divine power and human determination be perceived. According to Milton's Paradise Lost, Predestination and free-will both exist in the order of existence. Milton believes that God instituted possibilities and capacities of Descension and Ascension in the nature compulsorily. This idea confirms the elaboration and domination 
of Divine power throughout the world of creation, but the choosing between those possibilities is man's responsibility, which again indicates the freedom of will-power.

\section{Acknowledgements}

I would like to express my very great appreciation to Dr. Mohammad Reza Rakhshanfar for his insightful guidance in writing and compiling the article. My special thanks also go to Dr. Marziyeh Shariati, my very dear wife, who offered me her generous and emotional support in constructing this valuable research paper.

\section{References}

Arminius, J., \& Nichols, J. (1853). The works of James Arminius, D. D., formerly professor of divinity in the University of Leyden. Aubern \& Buffalo: Derby, Miller \& Orton.

Augustine, A. (2010). Saint Bishop of Hippo. In P. King (Ed. \& Trans.), On the free choice of the will, on grace and free choice, and other writings. Cambridge; New York: Cambridge University Press.

Baxter, R. (1671). God's goodness vindicated. London: Printed for N. Simmons.

---. (1707). The practical works: of the late reverend and pious Mr. Richard Baxter. London: Printed by J. Robinson, \& J. Lawrence for T. Parkhurst.

Boethius, A. (1962). In R. Green (Trans.), The consolation of philosophy. New York: Pearson.

Calvin, J., \& Bonnet, J. (2012). Letters of John Calvin: compiled from the original manuscripts and edited with historical notes, (Vol. 11). Edinburgh: Nabu Press.

Calvin, J. (2007). Institutes of the Christian religion. Peabody, Massachusetts: Hendrickson Publishers.

Cottrell, J. W. (1984). Conditional election. What the Bible Says About God the Ruler. Joplin: College Press.

Danielson, D. (1999). The fall and Milton's theodicy. The Cambridge Companion to Milton (p. 316). Cambridge: Cambridge University Press.

Foster, R. S., \& Rice, N. L. (1849). Objections to Calvinism as it is: in a series of letters addressed to N.L. Rice. Cincinnati: Hitchcock \& Walden; New York: Carlton and Lanahan.

Gilson, E. (1936). In A.H.C. Downes (Trans.), The spirit of mediaeval philosophy. Notre Dame: University of Notre Dame Press; New York: Scribner's.

Girardeau, J. L. (1890). Calvinism and evangelical Arminianism: Compared as to election, reprobation, justification, and related doctrines. Columbia: S.C., \& W. J. Duffie; New York: The Baker \& Taylor Co.

Gonzalez, J. L. (1983). A history of Christian thought. Nashville: Abingdon Press.

Goodwin, J. (1651). Apolytrosis Apolytroseos or redemption redeemed. London: Printed by J. Macock for L. Lloyd \& H. Cripps.

Hammond, H. (1674). The works of the reverend and learned Henry Hammond, D.D. London: Printed by E. Flesher for R. Royston, \& R. Davis.

Hick, John. (1967). In P. Edwards (Ed.), Evil, the problem of. New York: Macmillan.

Hirsch, E. D., Kett, J. F., \& Trefil, J. (2002). The new dictionary of cultural literacy: What every American needs to know. New York: Houghton Mifflin Harcourt.

Hyman, A., \& Walsh, J. J. (Eds.). (1973). Philosophy in the Middle Ages: The Christian, Islamic, and Jewish traditions. Indianapolis: Hackett Publishing Co.

Lovejoy, A. O. (1969). Critical essays on Milton from ELH. Baltimore: Johns Hopkins Press.

Milton, J. (1933). Areopagitica. Cambridge: Cambridge University Press.

---. (2005). In E. Elledge Scott, (Ed.), Paradise lost. New York, London: W. W. Norton \& Company.

Mollenkott, V. R. (1972). Milton's rejection of the fortunate fall. Milton Quarterly, 6 (1), 1-5.

Pierce, T. (1658). Self-condemnation. London: Printed by J.G. for R. Royston at the Angel in Ivy-lane.

Robert Cook, W. (1990). The Christian faith: a systematic theology in outline form. Portland: Western Conservative Baptist Seminary.

Schoenfeldt, M. (2003). In T. N. Corns (Ed.), Obedience and autonomy in paradise lost. A Companion to Milton. Oxford, Malden, Victoria: Blackwell.

Tomlin, C. (1792). Arius slain and Socinus mortally wounded. London: Printed for J.S. Jordan.

Wolfe, D. M., (Ed.). (1953). Complete prose works of John Milton (CPW). New Haven: Yale University Press.

Note:

Calvin is the founder of the belief systems of Presbyterian Church in Protestantism. Being dogmatic in his ideas, he was able to attract the attention of extremist Puritans to his creed. 